\title{
Alfentanil as an adjunct to thio- pentone and nitrous oxide in short surgical procedures
}

Alfentanil, a new narcotic analgesic with a rapid onset and short duration of action was used as an adjunct to thiopentone and nitrous oxide anaesthesia in 109 patients undergoing dilatation and curettage $(D \& C)$ or therapeutic abortion (TA). The mean alfentanil dose was $19.7 \pm$ $9.6 \mu \mathrm{g} \cdot \mathrm{kg}^{-1}$ (D\&C Group) and $23.3 \pm 6.6 \mu \mathrm{g} \cdot \mathrm{kg}^{-1}$ (TA Group), with a mean duration of anaesthesia of about 30 minutes. The anaesthetic effect was judged excellent in virtually all patients $(94.7$ per cent in the TA group and 96.7 per cent in the $D \& C$ group). There were no significant changes in haemodynamic parameters intraoperatively. Apnea or hypoventilation was observed in four patients and was easily reversed by naloxone. Most patients (95.4 per cent) demonstrated complete recovery of consciousness, motor activity, respiratory and circulatory function and skin colour within 60 minutes of arrival in recovery room. The only consistent side effect was minor chest wall rigidity which was eliminated by pretreatment with d-tubocurarine. One patient experienced a serious adverse reaction which was reversed with naloxone. We have found alfentanil to be well suited as an adjunct to nitrous oxide and thiopentone in short surgical procedures.

Key words

ANALGESICS: alfentanil; ANAESTHETICS INTRAVENous: thiopentone; COMPLICATIONS: muscle rigidity.

From the Départment d'Anaesthésie-Réanimation, Centre Hospitalier de Valleyfield, Valleyfield, Québec.

Address correspondence to: Dr. J.-P. Dechène, Départment d'Anaesthésie-Réanimation, Centre Hospitalier de Valleyfield, 150, Rue St-Thomas, Valleyfield, Québec J6T 6C1.
Alfentanil, an analogue of fentanyl, is a new narcotic analgesic with a very rapid onset and short duration of action; $1 / 3$ that of fentanyl in each case. $^{1,2,3}$ Alfentanil induces persistent postoperative analgesia without significant respiratory depression. ${ }^{4}$ Thus, alfentanil appears to be well suited as an analgesic for both short procedures and outpatient surgery.

In this study we investigated the suitability of alfentanil as an adjunct to nitrous oxide after thiopentone induction in 109 female patients undergoing short surgical procedures: either dilatation and curettage (D\&C) or therapeutic abortion (TA).

\section{Methods}

Informed consent was obtained from each patient.

One hundred and twenty female patients, ASA physical status Class I and II, were entered in the study. Of the 85 in the TA group, nine also underwent tubal ligations; these nine patients were used in the safety evaluation only. In the D\&C group, two of the 35 underwent other concurrent surgery (one diagnostic laparoscopy and one excision of gangrenous cervix); again these two patients appear in the safety evaluation only. Preoperatively, all patients were given $50 \mathrm{mg}$ of hydroxyzine and $0.4 \mathrm{mg}$ of atropine intramuscularly one hour prior to entering the operating room. All patients were induced with thiopentone in a 2.5 per cent solution administered intravenously.

Nitrous oxide-oxygen (4-2 litres) was first administered through a semi-closed absorption system using a face mask. Immediately following, alfentanil $(0.5 \mathrm{mg})$ was administered intravenously and supplemented with $0.25 \mathrm{mg}$ increments when signs of incomplete analgesia were observed. All patients received intravenous Ringer's lactate solu- 
TABLE I Demographic data

\begin{tabular}{|c|c|c|c|c|}
\hline & \multicolumn{2}{|l|}{$T A$} & \multicolumn{2}{|c|}{$D \& C$} \\
\hline Number of Patients & \multicolumn{2}{|c|}{76} & \multicolumn{2}{|l|}{33} \\
\hline $\begin{array}{l}\text { Age (years) } \\
(\text { mean } \pm S D)\end{array}$ & \multicolumn{2}{|c|}{$22.6 \pm 5.2$} & \multicolumn{2}{|c|}{$45.4 \pm 14.8$} \\
\hline $\begin{array}{l}\text { Weight (kg) } \\
\text { (mean } \pm \text { SD) }\end{array}$ & \multicolumn{2}{|c|}{$54.9 \pm 10.7$} & \multicolumn{2}{|c|}{$65.09 \pm 16.7$} \\
\hline \multirow[t]{2}{*}{$\begin{array}{c}\text { ASA physical } \\
\text { status class }\end{array}$} & I & II & I & II \\
\hline & 47 & 29 & 15 & 18 \\
\hline \multirow[t]{2}{*}{ Smoking status } & $\$$ & NS & $\mathbf{S}$ & NS \\
\hline & 43 & 33 & 7 & 26 \\
\hline
\end{tabular}

$\mathrm{S}=$ Smoker

NS $=$ Non-smoker

tion. Patients undergoing TA also received syntocinon ( 30 units). D-tubocurarine $(3 \mathrm{mg}$ ) was administered to all except 20 patients in the TA group and ten in the $D \& C$ group. Patients undergoing additional surgical procedures such as tubal ligation, laparoscopy etc., received succinylcholine $80 \mathrm{mg}$, and a further $9-15 \mathrm{mg}$ of d-tubocurarine, followed at the completion of surgery by $0.8 \mathrm{mg}$ atropine and $2.5 \mathrm{mg}$ prostigmine.

Blood pressure, pulse and respiratory rate were measured, using a Datascope monitor, on entry into the operation room (control), following induction but prior to the surgical procedure, during maintenance, after alfentanil supplementary doses and at the completion of surgery. Tidal volume was monitored using a Wright respirometer. A subjective evaluation of the anaesthetic effect during surgery was made by the anaesthetist.

Postanaesthetic recovery room (PARR) data (motor activity, respiratory function, circulatory function, degree of consciousness and skin colour) were recorded on arrival in the recovery room and every 30 minutes thereafter, using the method described by Aldrete and Kroulik. ${ }^{5}$ The time taken to achieve a PARR score of two for each individual criterion was noted.

\section{Results}

Demographic data for the two surgical groups are summarized in Table I. As expected, the mean age of the D\&C group was higher than that of the TA group with 94.7 per cent of patients in the TA group being 30 years of age or less and 78.9 per cent in the D\&C group being older than 30. Approximately one half of the patients in both groups were ASA physical status class I with the remainder being class II. Significantly more $\left(x^{2}=11.6, \mathrm{p}<0.01\right)$ patients in the TA group were smokers, compared to the D\&C group.

Table II summarizes the intraoperative data. The majority of patients in both groups ( 92.7 per cent) received between 0.5 and $1.5 \mathrm{mg}$ of alfentanil as the total dose. The mean dose of alfentanil administered was approximately $20 \mathrm{mg} \cdot \mathrm{kg}^{-1}$ for both groups.

The duration of anaesthesia was 30 minutes or less for 51 patients (67.11 per cent) in the TA group and 23 patients ( 69.7 per cent) in the D\&C group. All patients recovered within 40 minutes. Changes in haemodynamic parameters intraoperatively were minimal, with only two patients in the D\&C group showing a decrease in blood pressure ( $>10 \mathrm{mmHg}$ ) after alfentanil. The anaesthetic effect was judged "excellent" in virtually all patients ( 94.7 per cent in the TA groups and 96.7 per cent in the D\&C group).

Adverse reactions are summarized in Table III. Chest wall rigidity was observed in all patients not receiving d-tubocurarine or other muscle relaxants. One patient in the $D \& C$ group had a serious adverse reaction. This patient experienced laryngospasm, tachycardia, cyanosis and disturbing chest wall rigidity immediately following the ad-

TABLE II Intra-operative data (mean \pm SD)

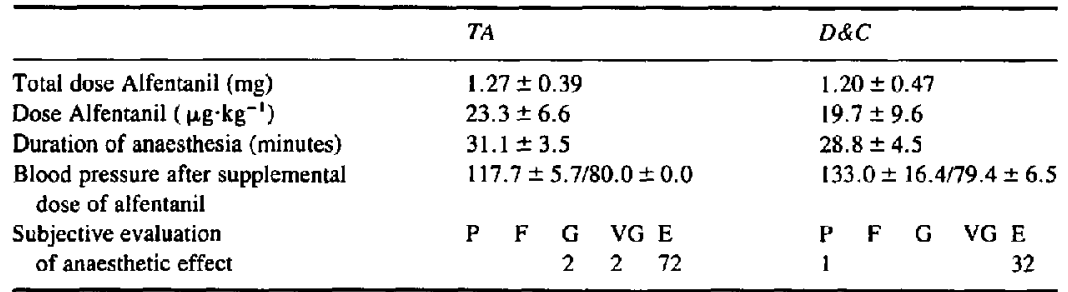

P-poor; F-fair; G-good; VG-very good; E-excellent. 
TABLE III Adverse reactions

\begin{tabular}{|c|c|c|c|}
\hline $\begin{array}{l}\text { Patient } \\
\text { Group }\end{array}$ & Side effect & $\begin{array}{l}\text { Number } \\
\text { patients }\end{array}$ & Comments \\
\hline TA & Apnoea & 2 & Reversed with naloxone \\
\hline \multirow[t]{4}{*}{$n=76$} & Hypoventilation & 3 & Reversed with naloxone \\
\hline & Bradycardia & 1 & Reversed with atropine \\
\hline & Non-disturbing chest wall rigidity & 19 & $\begin{array}{l}\text { These patients had not received d-tubocurarine or other muscle } \\
\text { relaxants }\end{array}$ \\
\hline & Prolonged recovery & 1 & Patient was a drug addict \\
\hline \multirow{3}{*}{$\begin{array}{l}\mathrm{D} \& \mathrm{C} \\
\mathrm{n}=33\end{array}$} & Apnoea & 1 & Spontaneous reversal after assisted respiration \\
\hline & $\begin{array}{l}\text { Laryngospasm tachycardia cyanosis } \\
\text { and minor chest wall rigidity }\end{array}$ & 1 & Reversed with naloxone \\
\hline & Nondisturbing chest wall rigidity & 7 & $\begin{array}{l}\text { These patients had not received d-tubocurarine } \\
\text { or other muscle relaxants }\end{array}$ \\
\hline
\end{tabular}

ministration of $0.5 \mathrm{mg}$ of alfentanil. An additional increment of alfentanil $0.5 \mathrm{mg}$ was given to deepen anaesthesia. Since these problems continued, they were immediately reversed by the administration of naloxone. Apnea or hypoventilation was observed in six other patients immediately following anaesthesia. Naloxone was given for reversal of these symptoms prior to the patients leaving the operating room.

Table IV summarizes recovery room data for both patient groups. Respiratory and circulatory function and skin colour were normal on arrival in the recovery room in virtually all patients. All patients in the D\&C group and 93.4 per cent of patients in the TA group showed complete recovery of combined criteria within 60 minutes of arrival in the recovery room.

Recovery time for all criteria was also compared according to smoking status. Smoking and nonsmoking patients were further divided into two groups: those with complete recovery of all criteria in 30 minutes or less and those with complete recovery requiring longer than 30 minutes. Smokers were more likely to recover in 30 minutes or less than were non-smokers. In the combined group, 39 (78.0 per cent) smokers versus 35 (59.3 per cent) non-smokers recovered in 30 minutes or less $\left(X^{2}=4.331, p=0.037\right)$. This was also seen in the TA group with 33 (76.7 per cent) smokers versus 18 (54.4 per cent) non-smokers recovering in 30 minutes or less $\left(X^{2}=4.168 \mathrm{p}=0.041\right)$. Although the trend was similar for the D\&C group with six (85.7 per cent) of the smokers and 17 (65.4 per cent) of the non-smokers recovering in 30 minutes or less, the lack of statistical significance for the $\mathrm{D} \& \mathrm{C}$ group results from the small numbers in each category.

\section{Discussion}

The use of narcotic analgesics is limited by the occurrence of respiratory depression when higher doses are administered. Because the respiratory depression may last longer than the analgesic effect, patients either require narcotic antagonists or assisted ventilation. Thus, these agents are not ideally suited for use either in surgical procedures of short duration or on an outpatient basis.

In this study we demonstrated that alfentanil is a suitable adjuvant to thiopentone and nitrous oxide in short surgical procedures. The level of anaesthesia and anaesthetic control was judged excellent in the vast majority of patients, while intraoperative respiratory depression was rare and easily reversed when it accurred. Although a recent report has described a decrease in mean blood pressure after alfentanil infusion in patients with cardiovascular disease, ${ }^{6}$ no adverse haemodynamic effects after alfentanil were observed in the present study. However, the dose of alfentanil used here was almost one tenth that in the former study where alfentanil was used as an anaesthetic induction agent. Other studies where alfentanil was used at a comparable dose described minimal haemodynamic effects. ${ }^{3.7-9}$

In agreement with other publishered reports ${ }^{6,7}$ the only consistent side effect observed with alfentanil was minor chest wall rigidity in 26 patients entered during the initial stages of the study. 
TABLE IV Recovery room criteria

\begin{tabular}{|c|c|c|c|c|c|c|}
\hline \multirow[b]{2}{*}{ Criterion } & \multirow[b]{2}{*}{ Group } & \multicolumn{5}{|c|}{ Number of patients with complete recovery score } \\
\hline & & $\begin{array}{l}\text { Time i } m \\
\text { Arrival }\end{array}$ & 30 & 60 & 90 & 120 \\
\hline $\begin{array}{l}\text { Motor } \\
\text { activity }\end{array}$ & $\begin{array}{l}\mathrm{TA} \\
\mathrm{D} \& \mathrm{C}\end{array}$ & $\begin{array}{l}8 \\
9 \\
(15.6)\end{array}$ & $\begin{array}{l}57 \\
23 \\
(89.0)\end{array}$ & $\begin{array}{l}10 \\
1 \\
(99.1)\end{array}$ & $\begin{array}{l}1 \\
(100.0)\end{array}$ & \\
\hline $\begin{array}{l}\text { Respiratory } \\
\text { function }\end{array}$ & $\begin{array}{l}\text { TA } \\
\text { D\&C }\end{array}$ & $\begin{array}{l}76 \\
33 \\
(100,0)\end{array}$ & & & & \\
\hline $\begin{array}{l}\text { Circulatory } \\
\text { function }\end{array}$ & $\begin{array}{l}\text { TA } \\
\text { D\&C }\end{array}$ & $\begin{array}{l}72 \\
29 \\
(92.7)\end{array}$ & $\begin{array}{l}4 \\
3 \\
(99.1)\end{array}$ & $\begin{array}{l}1 \\
(100.0)\end{array}$ & & \\
\hline $\begin{array}{l}\text { Degree of } \\
\text { consciousness }\end{array}$ & $\begin{array}{l}\text { TA } \\
\text { D\&C }\end{array}$ & $\begin{array}{l}2 \\
2 \\
(3.7)\end{array}$ & $\begin{array}{l}49 \\
21 \\
(67.9)\end{array}$ & $\begin{array}{l}20 \\
10 \\
(95.4)\end{array}$ & $\begin{array}{l}4 \\
(99.1)\end{array}$ & $\begin{array}{l}l \\
(100.0)\end{array}$ \\
\hline Skin colour & $\begin{array}{l}\mathrm{TA} \\
\mathrm{D} \& \mathrm{C}\end{array}$ & $\begin{array}{l}74 \\
33 \\
(98.2)\end{array}$ & $\begin{array}{l}2 \\
(100.0)\end{array}$ & & & \\
\hline All criteria & $\begin{array}{l}\text { TA } \\
\text { D\&C }\end{array}$ & $\begin{array}{l}2 \\
2 \\
(3.7)\end{array}$ & $\begin{array}{l}49 \\
21 \\
(67.9)\end{array}$ & $\begin{array}{l}20 \\
10 \\
(95.4)\end{array}$ & $\begin{array}{l}4 \\
(99.1)\end{array}$ & $\begin{array}{l}1 \\
(100.0)\end{array}$ \\
\hline
\end{tabular}

Values in parentheses represent cumulative per cent of patients recovered in the combined groups.

Subsequent patients entered in the study were "pre-treated" with d-tubocurarine, eliminating this side effect entirely. As noted above, one patient did have a serious adverse reaction, which included chest wall rigidity.

As previous studies have also demonstrated, ${ }^{10.12}$ postoperative recovery times after alfentanil were short although no attempt was made in the present study to compare recovery times after alfentanil anaesthesia with those of fentanyl or other narcotics. In general, recovery times for smokers in the combined group, and the TA group alone, tended to be shorter than those of the non-smokers. The lack of significance of this difference in the $D \& C$ group may be attributable to the small sample size.

In summary, the smooth, uneventful intraoperative course in almost all patients, and short recovery time with a minimum of side effects render alfentanil well suited as an adjunct to nitrous oxide and thiopentone in short surgical procedures.

\section{Acknowledgement}

I wish to thank Janssen Pharmaceutica Inc. for supplying the alfentanil in support of this research and for their advice during the study.

\section{References}

1 de Castro J, Van de Water A, Wouters $L$ et al. A comparative study of eight narcotics in dogs. Acta Anaesthesiol. Belg. 1979; 30: 5-54.

2 Brown, JH, Pleuvry BJ, Kay B. Respiratory effects of a new opiate analgesic, R 39,209 , in the rabbit: comparison with fentanyl. Br J Anaesth 1980; 52: $1101-6$.

3 Van Leeuwen L, Deen L, Helmers JHJH. A comparison of alfentanil and fentanyl in short operations with special reference to their duration of action and post-operative respiratory depression. Anaesthetist 1981; 30: 397-9.

4 van Leeuwen $L$, Deen $L$. Alfentanil, a new, potent and very short-acting morphinomimetic for minor operative procedures. Anaesthesist, 1981; 30: 115-7.

5 Aldrete $J A$, Kroulik $D$. A post-anaesthetic recovery score. Anesth Analg 1970; 49: 924-33.

6 Bartkowski RR, McDonnell TE. Alfentanil as an anesthetic induction agent. A comparison with thiopental-lidocaine. Anesth Analg 1984; 63: 330-4.

7 Nauta J, de Lange S, Koopman D et al. Anesthetic induction with alfentanil: a new short-acting narcotic analgesic. Anesth Analg 1982; 61: 267-72.

8 Nauta J, Stanley, TH, de Lange S, Koopman D, 
Spierdijk J, van Kleef J. Anaesthetic induction with alfentanil: comparison with thiopental, midazolam, and etomidate. Can Anaesth Soc J 1983; 30: 53-60.

9 Hull, CJ, Jacobson L. A clinical trial of alfentanil as an adjuvant for short anaesthetic procedure. $\mathrm{Br}$ J Anaesth 1983; 55: 173S-178S.

10 Sinclair $M$, Cooper $G M$. Assessment of recovery from day-case anaesthesia supplemented with alfentanil. Br J Anaesth 1983; 54: $1138 \mathrm{P}$.

11 Kay $B$, Venkataraman $P$. Recovey after fentanyl and alfentanil in anaesthesia for minor surgery. Br J Anaesth 1983; 55: 1695-1715.

12 Cooper GM, O'Connor M, Mark J, Harvey J. Effect of alfentanil and fentanyl on recovery from brief anaesthesia. Br J Anaesth 1983; 55: 179S-182S.

\section{Résumé}

L'alfentanil, un nouveau narcotique analgésique, à action courte et rapide fût utilisé comme sédation complémentaire au thiopentone associé au protoxyde d'azote dans 109 cas de curetage etlou avortement thérapeutique.

La dose moyenne d'alfentanil se situait aux environs de $20 \mu \mathrm{g} \cdot \mathrm{kg}^{-1}$ avec une durée anesthésique d'environ 30 minutes.

L'effet anesthésique fût jugé excellent dans presque tous les cas ( 94.7 pour cent pour les avortements et 96.7 pour cent pour les curetages). Durant l'opération, il n'y a pas eu de changements significatifs dans les paramètres hémodynamiques. L'apnée ou l'hyperventilation s'est produite chez quatre patientes et fût rapidement corrigée par le naloxone.

La plupart des patients (95.4 pour cent) ont démontré un réveil complet à la salle de recouvrance en dedans de 60 minutes et ceci en ce qui concerne leur activité motrice, leur fonction circulatoire et respiratoire ainsi que la coloration des téguments.

Au début de cette étude, le seul effet secondaire persistant fat une légère rigidité de la cage thoracique qui fât éliminée par la suite par l'administration préventive de la d-tubocurarine. Une réaction secondaire plus sérieuse, rapidement contrôlée par l'administration du naloxone, a eu lieu chez un patient.

En résumé, au cours de cette étude. l'alfentanil s'est avéré une excellente sédation complémentaire à l'anes. thésie au thiopental sodique associê au protoxyde d' azote dans les interventions mineures gynécologiques de courte durée. 